\title{
A DOCTRINAL RESEARCH PERSPECTIVE OF MASTER'S DEGREE STUDENTS IN ACCOUNTING
}

\author{
D. Coetsee*
}

PhD Candidate

School of Accounting Sciences

e-mail: dcoetsee@uj.ac.za

\author{
P. Buys* \\ WorkWell Research Unit/School of Accounting Sciences \\ e-mail: pieter.buys@nwu.ac.za \\ *North West University \\ Potchefstroom Campus \\ Potchefstroom, South Africa
}

\section{ABSTRACT}

This article reflects on the incorporation of doctrinal research in the curriculum of a master's degree programme in accounting at a South African university. Since accounting concepts, principles and rules are more developed in practice through a process of consensus, the question is whether there is place for doctrinal research in accounting research. Doctrinal research is a research approach that describes, interprets and critisises the underlying doctrines developed in authoritative practice-based documents of a field of enquiry. In the master's degree programme doctrinal research is introduced as an alternative research approach to conventional research approaches to develop the students' skills to question the doctrines. The perspective of the master's degree students is obtained through structured interviews from which different themes are identified by thematic analysis. The participant students agreed that doctrinal research has an important role to play in accounting research. The students also agree that their critical engagement with the underlying doctrines of accounting has improved significantly and that deeper understanding of the concepts and principles of accounting was created.

Keywords: accounting research, doctrinal research, doctrinal thinking, expository research, reform-orientated research, master's degree students, theoretical research

\section{INTRODUCTION}

In a course work master's degree programme at a South African university, students were introduced to conventional research approaches and to doctrinal research, a research approach normally applied in legal research. Doctrinal research was introduced as an alternative research approach to conventional research approaches. Doctrinal research was also incorporated in the 
master's degree programme as a means to develop technical application abilities.

The conventional research approaches incorporated in the master's degree research methodology course work included the entire spectrum of social research approaches, from positivistic (quantitative), interpretative (qualitative) to critical (more theoretical) research. The process of applying the scientific method to falsify hypotheses was also explained and how the scientific method differs from other more qualitative and theoretical methods. Specifically, in the Accounting theory module, the way in which these different research approaches are applied in accounting theory to create theory was considered.

Doctrinal research is a research methodology that interprets, assesses and develops the doctrines (the concepts, rules and principles) on which a field of enquiry is based (Hutchinson and Duncan 2012). Doctrinal research differs from conventional research approaches in that the focus is on the underlying doctrines (Hutchinson and Duncan 2012) and not on the development of theory through empirical research processes (Chua 1986; Chynoweth 2008).

In the master's degree programme, the suggestion is made that there is a place for doctrinal research in accounting to develop and critically evaluate the underlying concepts, principles and rules of accounting alongside other research approaches. Accounting, in this respect refers, to the narrower perspective of financial accounting, which refers to the concepts, principles and rules on which financial statements are based through the financial reporting process. Broader applications of the accounting discipline, such as management accounting, auditing and other broader reporting aspects, such as sustainability and integrated reporting, fall outside the scope of this article.

\section{RESEARCH PROBLEM}

Traditionally, accounting training at South African universities mainly focused on the practical training of professional accountants and not specifically on research training (Van der Schyff 2008; West 2006). West $(2006,131)$ concluded as follows on the South African accounting research culture:

The inquiry regarding the position of South African accounting research in the global context reveals that the outputs of accounting academics have not matched those of professional South African accountants, that the local contribution to the global accounting literature has been poor, but that there are nevertheless opportunities for conducting and publishing significant research.

However, it may be argued that the research culture of accounting academics is changing in South Africa due to the greater strive by most accounting departments at South African universities to create a research culture supported by several comments by accounting 
academics that change is needed in South Africa (Hesketh 2011; Lubbe 2014; Venter and De Villiers 2013). This changed research culture is leading to an increased level of published accounting research by South African accounting academics. However, most accounting academics in South Africa are only introduced to research training in their master's degree studies, after they have completed their professional qualifications. An important objective of master's degrees in South Africa, including course work master's degrees, is therefore to introduce students to different research approaches.

The issue in this article is whether such research training should include doctrinal research, a perspective that is not specifically addressed or supported by international accounting literature. It is a stated fact in accounting literature that sufficient theory to develop accounting concepts and principles is not developed in accounting research (Gaffikin 2008; Inanga and Schneider 2005). Accounting concepts and principles are also more developed through practice than research (Parker, Guthrie and Linacre 2011; Singleton-Green 2009). Doctrinal research is therefore introduced in the master's degree programme as an alternative research approach that does not develop theory, but focuses on the underlying concepts, principles and rules (the doctrines) of accounting. This raises the research question as to whether a doctrinal research perspective, and therefore doctrinal thinking, could be developed in master's degree students to instil the underlying doctrines of accounting as a substitute for the reliance on theory in accounting research.

\section{RESEARCH OBJECTIVE AND STRUCTURE}

The objective of this article is to reflect on the incorporation of doctrinal research in the curriculum of a master's degree programme from the perspective of the master's degree students after they have completed the first year of their master's degree studies. The perspective of the master's degree students is obtained through structured interviews.

The objective of reflecting on the development of doctrinal research in master's degree students is presented in this article through a structured process. The next section begins by conceptualising doctrinal research and doctrinal thinking and explaining how these concepts could be applied in accounting education and research. Thereafter, the nature of the process applied in the master's degree programme to educate the students on both practical and research skills is explained. Then follows the nature of the research methodology applied to identify core themes from the structured interview data. Lastly, the results are presented and interpreted by discussing the reasoning for the core themes identified in the research process. 


\section{CONCEPTUALISING DOCTRINAL RESEARCH AND DOCTRINAL THINKING}

The focus of doctrinal research, as stated before, is on the doctrines that are developed in a field of enquiry (Hutchinson and Duncan 2012; Singhal and Malik 2012) and not on the development of theory through conventional research. The doctrines are the concepts, rules and principles on which a field of enquiry is based (De Jong, Van Arensbergen, Daemen, Van der Meulen and Van den Besselaar 2011; Hutchinson and Duncan 2012). The doctrines are normally developed in practice by reaching consensus by practitioners and other role players (Van Gestel and Micklitz 2014; Von Bogdandy 2012) through a process of analysing and synthesising the underlying concepts, principles and rules (Hutchinson and Duncan 2012; McKerchar 2008). Doctrinal research is therefore relevant in any field of enquiry, such as law and accounting, where principles and rules are developed through a process of consensus. The developed doctrines are then regarded as a substitute for theory.

Academics for instance contribute to the process of developing doctrines by being directly involved in the practical process of consensus or indirectly through the academic debate in academic journals (Hutchinson and Duncan 2012; Kazmierski 2014; McKerchar 2008). The process of consensus could be, for instance, new legislation that is developed through a legislative process or a financial reporting standard developed through the due diligence process of the standard-setter, such as the International Accounting Standards Board (IASB). The fact that financial reporting standards are written into the legislation of many jurisdictions to create legal backing ${ }^{1}$ thereof, makes these standards also legal documents in the legal system.

Van Hoeke $(2011,1)$ discusses the history of doctrinal research and declares that through the Middle-Ages the ‘authoritative interpretation’ of doctrinal research was regarded as very important research that was replaced in many disciplines by empirical research from the seventeenth century, but especially from the nineteenth century. He states that doctrinal research is in essence a hermeneutic discipline, similar to the study of literature that interpreted texts, such as legislation and case law. Doctrinal research could thus be regarded as interpreted research of documents to identify the underlying doctrines therein.

Chynoweth $(2008,30)$ confirms that doctrinal research is firstly an 'interpretative, qualitative analysis' to prescribe what the law is by asking 'what is the law?' for any specific situations. Doctrinal research, however, also has a deeper side that questions the appropriateness of the developed doctrines through more critical research (Coetsee and Buys 2016; Kazmierski 2014). Doctrinal research is therefore a mixture of interpretive and critical analysis, but can also be descriptive if a specific law application is described.

Doctrinal research is therefore a very important research tool where the functioning of 
practice is based on underlying principles and rules developed in practice. These principles and rules are not legitimated through research, but through the sovereignty of the source (Hutchinson and Duncan 2012). For instance, the source of legal doctrine is legislation and case law and the source of accounting doctrine is the work of the standard-setters. It is important that academics must question these doctrines. Doctrinal research provides a means of interpreting and criticising these doctrines.

Doctrinal research could take different forms. Hutchinson and Duncan (2012) states that the researcher chooses the breadth and depth of the research. As a starting point, the expository aspect is considered first. As indicated above, it asked 'what is the law?' Such research explains what the law for specific fact patterns is and is therefore described as expository research (Chynoweth 2008), which is regarded as applied research in a professional constituency. The term expository research is derived from the narrow description of doctrinal research by the Pearce Committee: ${ }^{2}$ 'Research which provides a systematic exposition of the rules governing a particular legal category, analyses the relationship between rules, explains areas of difficulty and, perhaps, predicts future developments’ (Hutchinson and Duncan 2012, 101).

Doctrinal research is thus firstly a description of the current law, but turns to interpretation when the current law is applied in practice when opinions about the current law is provided by professionals and academics. In accounting, it would be the description and interpretation of the applicable financial reporting standard, the law of accounting.

Law students are taught to describe and interpret the legislation and case law. Through the training of law students, 'doctrinal thinking' is installed (Hutchinson and Duncan 2012; Kazmierski 2014), and this thinking is based on two premises. To resolve any practical issue in law there are (1) facts of the circumstances and (2) the appropriate authority (the legislation and case law) to resolve the issue. Law students are specifically trained in both the skills of identifying facts and applying the underlying authority. This could be seen in the fact that several legal research books such as those by Knowles and Thomas (2006) and Tjaden (2010) do not focus on any conventional research approaches, but on the process to identify facts and to establish the related authority. Although professional accounting students are, in principle, also trained to resolve practical issues by applying the authority, the depths of developing these skills are not the same.

It is important that doctrinal thinking must be distinguished from doctrinaire thinking, which is described (Merriam-Webster 2017; Oxford Dictionaries 2017) as a strictly or stubborn following of a theory (or by implication a doctrine) without regard to practical issues or disagreements. Doctrinal thinking is in contrast a process of identifying and questioning the 
underlying doctrines to resolve a practical issue, focussing on what the underlying authority is or should be. Identifying and debating the correct authority to resolve practical issues is the essence of doctrinal research.

Doctrinal research also has a deeper, reformed-orientated perspective, which questions the appropriateness of the underlying doctrines. Doctrinal research and doctrinal thinking therefore also embrace the ability to critically assess the appropriateness of the doctrines developed in a field of enquiry (Hutchinson and Cuffe 2004; Kazmierski 2014). In this regard, the doctrinal research literature refers to law reform-orientated research, which is defined by the Pearce Committee as 'Research which intensively evaluates the adequacy of existing rules and which recommends changes to any rules found wanting' (Hutchinson and Duncan 2012, 101). Reform-orientated-research is a form of critical research that questions 'what the law should be’ (Chynoweth, 2008).

Reform-orientated doctrinal research can be regarded as a substitute for normative research that lost its appetite in accounting research when mainstream positivistic research became the norm (JeanJean and Ramirez 2009; Parker 2012). Reform-orientated research is therefore a means to bring normative research back to accounting research. However, the nature differs from conventional normative research in that the researcher is much more an insider in the research process (Burns and Hutchinson 2009; Kazmierski 2014). The researcher is therefore part and parcel of the practical problem that is researched. In contrast, JeanJean and Ramirez (2009) specifically state that conventional normative theorists in accounting distance themselves from practice to create legitimacy for their research. However, in doctrinal reformorientated research, legitimacy is created through the appropriateness of the process and discourse that are applied (Chynoweth 2008; Razak 2009). Such reform-orientated research could be a means in accounting research to bring researchers closer to practice and is a reason why master's students are introduced to it. The experience of the researcher is, however, that Accounting students battle with the nature of such reform-orientated research, as it requires good writing and interpretation skills, which are more instilled in Law students through the doctrinal thinking process (Hutchinson and Cuffe 2004).

A third, deeper aspect of doctrinal research is so-called theoretical research, which is defined by the Pearce Committee as 'research which fosters a more complete understanding of the conceptual bases of legal principles and of the combination effects of a range of rules and procedures that touch on a particular area of activity' (Hutchinson and Duncan 2012, 101). The key concepts underpinning accounting fundamentals are captured in the conceptual framework. Theoretical doctrinal research could be applied in accounting research to create a deeper 
understanding of the nature of the concepts that underpin the conceptual framework and the financial reporting standards.

Doctrinal research is introduced to the course work master's degree to develop the ability of students to apply their accounting knowledge to advanced issues in accounting (expository research), but also to develop the ability of students to question the underlying concepts, rules and principles of accounting (reform-orientated research) and to provide a deeper understanding of the conceptual basis of the concepts, rules and principles (theoretical research). Similar to Law students, it would be ideal if these skills could become part of the daily practice of accounting students. Doctrinal research could also be used by other disciplines to question the authoritative guidance on which the disciplines are based.

\section{THE MASTER'S DEGREE PROCESS}

The students were interviewed upon the completion of the first year of the master's degree programme after they were educated in both conventional and doctrinal research through their normal participation in the academic process. During the first year of the master's degree programme, the students participate in three different course work modules. In the first semester, the students completed an Accounting theory module and in the second semester, a module on new developments in accounting. Additionally, the students completed a Research methodology module presented by a research expert that was spread over the first eight months of the year. The outcome of the research methodology module was a concept research proposal on a topic that they plan to utilise in their research dissertation component.

In the Accounting theory module, the students are introduced to different aspects of accounting theory that they did not do in their previous, more professional-orientated, studies in South Africa. The aim of the Accounting theory module is to broaden the students' knowledge of different theories that are applied in accounting and how theory is developed in accounting by using different research approaches. The content of the module is based on both accounting theory textbooks and related published article research. The concepts of the doctrinal research approach were introduced in the module as an alternative to conventional theory development to develop different perspectives in the students.

The New developments module introduced the students to projects in accounting that the IASB is currently engaged in. The aim of this module is to develop the ability of students to critically interpret these new developments in accounting. In this specific year, a focus was placed on the concepts and principles developed in the new proposed conceptual framework to evaluate the appropriateness of the doctrines that underlie the concepts included in the 
conceptual framework.

The Research methodology module focused on all aspects of research that should be known to complete a research proposal at a master's level. The doctrinal research approach was not included in the research methodology module, since the focus was on conventional research approaches. The students completed four assignments that build on each other and cumulated in a proposed research proposal.

\section{RESEARCH METHODOLOGY}

The reflection of the development of doctrinal research in master's degree students in this article is captured in an interpretative research framework. The interpretive framework is based on the premises that social practices are socially constructed (Ryan, Scapens and Theobald 2002) and that social actors construct their own truth (Coetsee 2011). Research in the interpretative framework captures the perception and feeling of people; in this instance, the students, and is therefore qualitative in nature (Henning, Van Rensburg and Smit 2004). Qualitative research captures the perception and feeling of participants to create deeper understanding regarding a phenomena (Henning et al. 2004), which is in this instance the development of doctrinal research in Accounting master's degree students. The data to reflect on the development of doctrinal research in master's degree students was collected through structured interviews with each of the students. Structured interviews were chosen to get structured responses from each student to evaluate their understanding of the phenomena. The structured questions focused both on their perspective regarding doctrinal research and on their personal and professional development in this regard. The following questions were specifically included in the interviews:

- Do you think doctrinal research could be applied in accounting research?

- Do you think that accounting students should be trained in doctrinal research?

- Are accountants questioning the doctrines of accounting sufficiently?

- What is your perspective regarding doctrinal thinking?

- What is the role of academics in the process?

- Do you think that the underlying concepts (doctrines) of the conceptual framework of financial reporting are sufficiently developed?

- Has your perspective of critical engagement with the conceptual framework (or doctrines of accounting) changed?

- Was a deeper or complete understanding (doctrinal thinking) of the concepts underlying 
the conceptual framework created?

Thematic analysis was used to analyse the data in themes. Braun and Clarke $(2006,79)$ describe thematic analysis 'as a method for identifying, analyzing and reporting patterns (themes) within data'. Beattie, McInnes and Fearnley (2004) agree that thematic analyses could be used to code themes through both quantitative and qualitative (interpretative) analyses, depending on the size of the population. The theoretical position taken in the article is of deeper interpretative and qualitative research due to the small population.

Themes in thematic analyses could be identified through inductive or deductive ways (Braun and Clarke 2006; Fereday and Muir-Cochrane 2006). In this article, the deductive (also referred to as theoretical analyses) was chosen. Braun and Clarke $(2006,84)$ state that 'Theoretical analysis would tend to be driven by the researcher's theoretical or analytic interest in the area, and is thus more analyst-driven'. The specific data analyses in this article were driven by the main objective to assess the development of a doctrinal research perspective or thinking in accounting master's degree students, by asking the specific questions identified under the research objective. Each question was thematically analysed to identify the main themes. A direct link is purposely created between the questions asked and the themes identified. Validity was created through the coding process described below.

All interviews were conducted and coded by the researcher. Firstly, each interview was purposely transcribed to identify the main answer(s) of each participant and the reasoning for the answer(s). The answers of each student for each question were then coded in a table identifying (1) the main answer(s) of each participant and (2) the supporting reasoning for the answer. From the coding table for each question, the (1) main theme for each question was derived, (2) the main reasoning supporting the theme was identified, and (3) other aspects addressed were identified. If a participant provided information related to another question under a specific question, the data was transferred for coding to the correct question.

\section{RESULTS}

At the outset of their studies, the students were informed of the research project and that they had a choice not to partake therein. Twenty (90.9\%) of the 22 registered students partook in the research project, with one student being overseas when the interviews were conducted and the other student not completing all the modules of the first year of the master's degree. The demographic information of the 20 students who participated (hereafter participants) is presented in Table 1. 
Table 1: Demographic information

\begin{tabular}{|l|l|l|l|l|}
\hline Race & Black & Indian & White & \\
\hline & 15 & 3 & 2 & \\
\hline Gender & Male & Female & & \\
\hline & 13 & 7 & & \\
\hline Occupation & Academic & Technical expert & Corporate position & Auditor \\
\hline & 9 & 7 & 3 & 1 \\
\hline
\end{tabular}

The analysis of the results identified eight themes that relate specifically to each question identified in the research objective above.

\section{Theme one: Doctrinal research should be applied in accounting}

The view of most of the participants was that doctrinal research should be applied in accounting research. Several different reasons for this view were expressed. One of the main reasons presented is that the concepts, principles and rules of accounting are mainly developed in practice through the standard-setting process and not significantly through typical academic scholarly processes. Doctrinal research is, in their view, more related to these concepts, principles and rules. The participants expressed that doctrinal research could contribute to debating, and therefore, developing these concepts, rules and principles. For this reason, one participant even argued that doctrinal research should be the main research approach applied in accounting research.

The participants are also of the opinion that accounting is, similar to the legal discipline, practice based and that its practitioners, more so than its academics, are involved in the process of developing the doctrines of accounting. The participants therefore argued that Accounting students should know about the doctrines of accounting and how these doctrines are developed. In their view, doctrinal research could be used to confirm the application in practice and could also contribute to understanding the basis of accounting.

Furthermore, the participants referred to a lack of a so-called theoretical base for accounting. This is an aspect also mentioned in the accounting theory literature by Gaffikin (2008) and Inanga and Schneider (2005), who are of the opinion that sufficient theory is not developed in accounting research. Nevertheless, most participants considered that (1) doctrines are more relevant to the practice of accounting than any theory development, (2) that conventional accounting research is not understood by practice and (3) that practice would better understand doctrinal research. One participant is even of the opinion that doctrines are the theoretical base on which practice is based.

Building hereon, one participant mentioned that the accounting concepts, principles and rules are more prescriptive than descriptive in nature and therefore implied that mainstream 
accounting research with its descriptive nature is less relevant to the development of accounting concepts, principles and rules. Doctrinal research, which is more normative in nature (Chynoweth 2008), could therefore, in the participants' view, contribute more to the development of the underlying doctrines of accounting. Participants also expressed the view that doctrinal research could fill gaps created by conventional research. In the academic literature, this gap is referred to as 'the failure of accounting research to improve accounting practice' (Inanga and Schneider 2005, 228) and 'research has become too far removed from the interest of the profession and practitioners' (Parker et al. 2011, 5).

On the somewhat negative side, three participants were sceptical regarding the application of doctrinal research in accounting, with one stating that the doctrines of accounting are not always developed sufficiently and that such a research approach has a limited application in accounting. A further participant was of the opinion that the legal practice is more based on rules and that such a legalistic application could possibly have a negative impact on accounting practice and development. Furthermore, the same participant also mentioned that lawyers have case law to test their doctrines, while accountants do not have a similar independent process to develop and test accounting doctrines. The third participant stated that a balance between different research methods should be created in accounting research, with a focus on more critical research. However, the participant believed that the critical thinking and link to practice aspect of doctrinal research are positive.

\section{Theme two: Accounting students should be trained in doctrinal research, especially on a master's degree level}

Although the participants agreed that accounting students should be trained in doctrinal research, they disagreed on which level it should be introduced. The general consensus was that doctrinal research should be part of master's degree programmes, since it provides a research approach alternative to conventional research approaches. Most participants agreed that understanding doctrinal research enhanced their critical thinking skills and through the education process of the master's degree they are questioning the concepts, principles and rules of accounting. It may therefore be argued that the perception that universities produce graduates that cannot think critically in accounting education (Parker et al. 2011) can be overcome through the introduction of doctrinal research. Some of the participants therefore expressed the need to introduce doctrinal research even earlier in the accounting education process to enhance students' ability to think critically and question accounting concepts, principles and standards.

Although the participants have been introduced to the conceptual framework in their 
earlier studies, they still believed, as discussed below in theme three, that they did not question the concepts and principles of accounting sufficiently. The introduction of doctrinal research approaches had changed their view and some believed that this change of view should be introduced earlier in the education process. One participant specifically declared that doctrinal thinking should be instilled in students earlier so that they understand how accounting is developed and to create a critical and interpretative skills perspective. The participants therefore agreed that there is a specific place for doctrinal research to create a link to practice and the underlying concepts and principles of accounting. Nevertheless, a strong view was expressed that all research approaches in accounting are important and that a balance should be created between the different research approaches. Students should understand the different research approaches and how they could be applied in accounting to resolve different issues.

\section{Theme three: Participants agreed that they did not question the doctrines of accounting sufficiently before this master's degree programme}

Most participants declared that before embarking on the master's degree road they were not trained in questioning the appropriateness of the doctrines of accounting and therefore in critical thinking. The overall view expressed is that they have previously taken the concepts and principles in the conceptual framework and financial reporting standards for granted, and were therefore more focused on the correct application of concepts and principles in practice and not on questioning the concepts and principles. In their view, their lecturers did not question the doctrines of accounting sufficiently themselves and therefore the students did not develop such critical skills. Some participants were of the opinion that their lecturers should have questioned the doctrines of accounting more and should have asked more questions about what and why certain concepts and principles were developed.

Some participants agreed that certain people in practice, such as regulators, standardsetters and technical accounting experts, are questioning the underlying doctrines of accounting, but do not think that accounting professionals as such are questioning the doctrines sufficiently. One participant, who is working in an accounting technical department of an auditing firm, for instance, declared that they typically only apply a specific financial reporting standard to the facts pertaining to a specific instance. It is only now, after the master's degree programme, that they are beginning to question the underlying concepts and principles of accounting case more. The overall view expressed is that the ability of accounting students to question the underlying concepts and principles of accounting should be developed more in accounting education. 


\section{Theme four: The participants perceived that they are not sufficiently trained in doctrinal thinking, but agree that their critical interpretation skills have increased}

Most of the participants agreed that they do not have a legal background and are therefore not sufficiently trained in doctrinal thinking. Nevertheless, they agree that their critical thinking skills have improved and they have a better ability to question the doctrines of accounting, since they have a better understanding of doctrinal research and were exposed to actual issues in accounting that are currently unresolved. For some participants, the master's degree has triggered their interest to read the Basis of Conclusion pertaining to the specific financial reporting standard in order to better understand the reasoning behind the standard. One participant, for instance, explained that the programme changed her way of thinking about accounting, how it should be applied and resulted in her starting to question the doctrines of accounting. It provided a better understanding of the process of developing accounting concepts and principles, and how and why the standard-setters arrived at certain conclusions. Another participant said that he is more sceptical and understands that some solutions might not be the best way forward.

As alluded to earlier, doctrinal thinking also includes (1) the process of identifying the facts of a practical accounting issue and (2) applying the appropriate authority to resolve the practical issue. Participants expressed the view that this process of doctrinal thinking has increased their technical ability. One participant explained that, in practice, they rely on the technical experts and that this process must be instilled more broadly in accounting students to obtain the ability to resolve technical issues themselves.

\section{Theme five: The participants expressed that academics should be more involved in the development of accounting doctrines and not rely mainly on the development through practice}

The overall theme expressed was that academics must question the doctrines of accounting more, and not to leave it for practice to develop. The participants were also of the opinion many lecturers are just accepting the doctrines without questioning it. Academics must become more involved in the development of accounting doctrines, and doctrinal research could create an avenue for such development. Therefore, in the view of some participants, academics must be more involved in doctrinal research that questions the appropriateness of the underlying doctrines developed through practice.

The view was also expressed that academics must create opportunities to debate the 
underlying doctrines and therefore create an academic discussion that critically evaluates the underlying doctrines. One participant specifically stated that academics were more involved in the development of doctrines in accounting when normative research was acceptable, but that this changed under the positivistic mainstream accounting research movement. Some participants expressed the view that a thorough critical thought process, where academics are involved in the development of accounting concepts, principles and rules, is not sufficiently developed in the accounting literature. Introducing doctrinal thinking in accounting education could contribute to such development processes.

\section{Theme six: Participants agreed that the doctrines of accounting as incorporated in the conceptual framework on financial reporting are not always developed sufficiently}

Most participants agreed that the conceptual framework of financial reporting established the underlying doctrines on which the accounting practice of financial reporting is based. They agreed that, through the process of reviewing the new proposed conceptual framework of financial reporting and comparing it with the existing conceptual framework, in the master's degree programme, they developed the ability to see the gaps and areas of uncertainty in the respective conceptual frameworks. They agreed that certain aspects of the new proposed conceptual framework, such as the objective, qualitative characteristics and features of the definition of assets, including the concept of control, are developed sufficiently, but that other aspects such as what creates a liability, the distinction between equity and liability, recognition, measurement and the transfer of items to other comprehensive income are not appropriately clarified to develop future standards. They also expressed a concern that if these identified concepts are not developed sufficiently, it could result in a different application on a standardsetting level that is not consistent with the conceptual framework. The concern is further that underdeveloped concepts could result in concepts and principles being developed on a standardsetting level rendering the conceptual framework as outdated in certain aspects.

\section{Theme seven: The critical engagement of the participants with the conceptual framework and underlying doctrines has changed}

The participants were directly asked whether their perspective of critical engagement with the conceptual framework of financial reporting and the underlying doctrines changed. Most participants answered positively and stated that through the master's degree process they have started questioning the conceptual framework and underlying doctrines, whereas before they 
had less understanding or insufficient knowledge.

Although most viewed the conceptual framework still as appropriate, they have developed knowledge and understanding of unresolved issues and uncertainties. They developed a much more critical engagement. The participants made comments such as that they consider the why question now, think more widely, question more and actually have now opinions about issues. Most participants' perceptions changed from accepting the conceptual framework to one that questions the conceptual framework. They also expressed the opinion that they understood the underlying doctrines of accounting better.

Only two participants said that their critical engagement of the conceptual framework of financial reporting has not changed. They still see the conceptual framework as the basis or foundation of financial reporting standards, but acknowledged that their understanding of the conceptual framework as well as the underdeveloped aspects improved.

\section{Theme eight: Most participants agreed that a deeper understanding of the concepts of accounting was created}

This theme is directly linked to some of the previous themes. With the exception of two participants, all agreed that a deeper understanding of the concepts of accounting was created by reviewing the new proposed conceptual framework. Most participants declared that they question the concepts in the conceptual framework more than before and have a better understanding of the concepts, which, in turn, provides them with the ability to question the financial reporting standards more. One participant specifically stated that she thinks differently and falls back to the conceptual framework to clarify uncertainties in practice. This specific participant works in an accounting technical department of an audit firm and she also stated that a better understanding of the concepts of accounting and the link to the financial reporting standards helped her to improve her skills to write technical opinions. She is therefore more confident in her work. One participant also specifically stated that for the first time he understands the conceptual framework fully.

The two participants who responded more negatively did it for different reasons. The first participant stated that although he understands the unresolved issues with the conceptual framework better and therefore is more knowledgeable of uncertainties that exist, he is more confused due to the unresolved uncertainties. Another stated that he realised that financial reporting is more complicated and complex than he realised before. 


\section{CONCLUSION}

This article reflects on students' perception of the introduction of doctrinal research as an alternative to conventional research approaches in an accounting master's degree programme. The question is whether a doctrinal research perspective, and therefore doctrinal thinking, could be developed in master's degree students to instil the underlying doctrines of accounting as a substitute for the reliance on theory in accounting research.

The literature indicates that doctrinal research is a very important research approach when the practice of a discipline is based on principles and rules 'the doctrines' developed in practice through a process of consensus and not through any theory building process. Legitimacy for theses doctrines is created through authoritative documents such as legislation, case law and discipline standards. Doctrinal research is used to describe, interpret and criticise the doctrines of practice establish in these documents and provides a means to academics to question the appropriateness of the doctrines. The implication for higher degree research in general is that an alternative research approach exits to question the bases of authoritative documents developed in any discipline through a process of consensus.

The article found that the participants are very positive regarding the introduction of doctrinal research in the master's degree programme. The main reasons identified are that accounting concepts and principles are more developed through practice than research, that doctrinal research creates a theoretical base to evaluate the concepts and principles of accounting, and that doctrinal research brings normative aspects back to accounting research.

The participants also identified that their critical thinking skills have improved. Their general view of accounting has changed from accepting the concepts and principles to questioning them. Through the master's degree process, a deeper understanding of the concepts and principles of accounting was created and their ability to question these concepts improved. Doctrinal research also developed the technical ability of students to apply specific authority to practical fact patterns. Specifically, the participants understand the development process of accounting better and are able to identify uncertainties and aspects not developed sufficiently.

The participants also felt that the educational process of accounting students could be changed. Overall, they believed that in their previous accounting education, they were not challenged sufficiently to question the concepts and principles of accounting. They therefore expressed the view that Accounting lecturers should become more involved in doctrinal research, not only to be more involved in the development of concepts and principles in accounting, but also to develop the skills to question the concepts and principles of accounting more. 
A strong proviso was, however, expressed by some of the participants that a balance should been created between different research approaches. Although doctrinal research could contribute to different kinds of research that is more practice based and normative in nature, the benefit of other research approaches should not be disregarded. They feel that master's degree students should be trained in all the different research approaches, although one participant specifically stated that doctrinal research should be the main research approach in accounting.

Several opportunities for further research exist. Research could be done to assess whether and how doctrinal thinking could be incorporated on all levels of accounting education to develop the critical and application skills of students. Further research could be conducted from a more educational perspective to identify the nature of transformative learning (Mezirow 2003) that happens in students and specifically through understanding and applying doctrinal research. The positive feedback of the participants regarding the improvement of their critical application abilities suggests that possible transformative learning happened.

The biggest shortcoming of doctrinal research is that it does not address the interdisciplinary nature of a discipline (Singhal and Malik 2012; Vick 2004) and the effect of broader social issues on the discipline (Razak 2009). Sustainability accounting and integrated reporting are designed to incorporate and address some of the broader social issues in accounting. Further research could investigate how doctrinal research could be applied to such broader perspectives. Another issue of doctrinal research is that methodology aspects and the theoretical base of doctrinal research are not developed specifically (Hutchinson and Duncan 2012; Westerman 2011). The nature of the methodology and theoretical base of doctrinal research could be further investigated and clarified. The incorporation of doctrinal research in the critical accounting research movement could also be investigated, questioning whether the nature of doctrinal research is not already incorporated in the movement without explicitly mentioning it.

\section{NOTES}

1. In South Africa, legal backing is created for International Financial Reporting Standards through the Companies Act.

2. The Pearse Committee's report published in 1987 defined the first category as doctrinal research based on the narrow perspective of doctrinal research. However, the Arthur Report of 1983 named the first category expository research to cater for a broader perspective of doctrinal research. Doctrinal research is therefore much broader than only expository research.

\section{REFERENCES}

Beattie, V., B. McInnes and S. Fearnley. 2004. A methodology for analysing and evaluating narratives in annual reports: A comprehensive descriptive profile and metrics for disclosure quality 
attributes. Accounting Forum 28: 205-236.

Braun, V. and V. Clarke. 2006. Using thematic analysis in psychology. Qualitative Research in Psychology 3: 77-101.

Burns, K. and T. Hutchinson. 2009. The impact of 'empirical facts' on legal scholarship and legal research training. The Law Teacher 43(2): 153-178.

Chua, W. F. 1986. Radical developments in accounting thought. The Accounting Review 16(4): 601632.

Chynoweth, P. 2008. Legal research. In Advance research methods in the Built Environment, ed. A. Knight and L. Ruddock, 28-38. West Sussex: Blackwell Publishing Ltd.

Coetsee, D. 2011. A comment on research frameworks applied in accounting research. South African Journal of Accounting Research 25(1): 81-102.

Coetsee, D. and P. Buys. 2016. Doctrinal research as a means to recover normative thinking in accounting. Studia UBB. Philosophia 61(3): 69-87.

De Jong, S. P. L., P. van Arensbergen, F. Daemen, B. van der Meulen and P. van den Besselaar. 2011. Evaluation of research in context: An approach and two cases. Research Evaluation 20(1): 61-72.

Fereday, J. and E. Muir-Cochrane. 2006. Demonstrating rigor using thematic analysis: A hybrid approach of inductive and deductive coding and theme development. International Journal of Qualitative Methods 5(1): 80-92.

Gaffikin, M. J. R. 2008. Accounting theory: Research, regulation and accounting practice. Frenchs Forest, NSW: Pearson Education Australia.

Henning, E., W. van Rensburg and B. Smit. 2004. Finding your way in qualitative research. Pretoria: Van Schaik Publishers.

Hesketh, J. B. 2011. Accounting academics' multiple challenges: Issues-driven learning offers a way forward. South African Journal of Accounting Research 25(1): 1-34.

Hutchinson, T. C. and N. Cuffe. 2004. Legal research project management: Skills extension for upper level law students. The Law Teacher 38(2): 159-181.

Hutchinson, T. C. and N. Duncan. 2012. Defining and describing what we do: doctrinal legal research. Deakin Law Review 17(1): 83-119.

Inanga, E. L. and W. B. Schneider. 2005. The failure of accounting research to improve practice: A problem of theory and lack of communication. Critical Perspectives on Accounting 16: 227-248.

JeanJean, T. and C. Ramirez. 2009. Back to the origins of positive theories: A contribution to an analysis of paradigm changes in accounting research. Accounting in Europe 6(1): 107-126.

Kazmierski, V. 2014. How much 'Law' in legal studies? Approaches to teaching legal research and doctrinal analysis in a legal study program. Canadian Journal of Law and Society July 2014: 114.

Knowles, J. and P. Thomas. 2006. Effective legal research. London: Sweet \& Maxwell Limited.

Lubbe, I. 2014. Educating professionals: Describing the knowledge agency of Accounting academics. Meditari Accounting Research 22(1): 107-207.

McKerchar, M. 2008. Philosophical paradigms, inquiry strategies and knowledge claims: Applying the principles of research design and conduct to taxation. eJournal of Tax Research 6(1): 5-22.

Merriam-Webster. 2017. Marriam-Webster Dictionary. https://www.merriam-webster.com/dictionary/ doctrinaire (Accessed 17 March 2017).

Mezirow, J. 2003. Transformative learning as discourse. Journal of Transformative Education 1(1): 5863.

Oxford Dictionaries. 2017. @ English Oxford living Dictionaries. https://en.oxforddictionaries.com/ definition/doctrinaire (Accessed 17 March 2017).

Parker, L. D. 2012. Beyond the ticket and the brand: imagining an accounting research future. 
Accounting and Finance 52: 1153-1182.

Parker, L. D., J. Guthrie and S. Linacre. 2011. The relationship between academic accounting research and professional practice. Accounting, Auditing and Accountability Journal 24(1): 5-14.

Razak, A. A. 2009. Understanding legal research. Integration and Dissemination March 2009: 19-23.

Ryan, B., R. W. Scapens and M. Theobald. 2002. Research method and methodology in finance and accounting. London: Thomson Learning.

Singhal, A. K. and I. Malik. 2012. Doctrinal and socio-legal methods of research: merits and demerits. Educational Research Journal 2(7): 252-256.

Singleton-Green, B. 2009. The communication gap: Why doesn't accounting research make a greater contribution to debates on accounting policy? Accounting in Europe 7(2): 129-145.

Tjaden, T. 2010. Legal research and writing. Toronto: Irwim Law Inc.

Van der Schyff, D. B. 2008. The essence of university and scholarly activity in accounting, with reference to a department of a South African university. Meditari Accountancy Research 16(1): $1-26$.

Van Gestel, R. and H-W. Micklitz. 2014. Why methods matter in European legal scholarship? European Law Journal 20(3): 292-316.

Van Hoeke, M. 2011. Legal doctrine: Which method(s) for what kind of discipline? In Methodologies of legal research: What kind of method for what kind of discipline? ed. M. Van Hoeke, 1-18. Oxford and Portland: Hart Publishing.

Venter, E. and C. de Villiers. 2013. The accounting profession's influence on academe: South African evidence. Accounting, Auditing \& Accountability Journal 26(8): 1246-1278.

Vick, D. W. 2004. Interdisciplinarity and discipline of law. Journal of Law and Society 31(2): 163-193.

Von Bogdandy, A. 2012. National legal scholarship in the European legal area: A manifesto. I-CON 10(3): 614-626.

West, A. 2006. A commentary on the global position of South African accounting research. Meditari Accountancy Research 14(1): 121-37.

Westerman, P. C. 2011. Open or autonomous? The debate of legal methodology as a reflection of the debate of law. In Methodologies of legal research: What kind of method for what kind of discipline? ed. M. van Hoeke, 87-110. Oxford and Portland: Hart Publishing. 